\title{
マウス尿酸トランスポーターmURAT1の性ホルモンによる 発現調節機構
}

滝上 裕一 細山田 真 木村 真規 柴崎 敏昭

目的

ヒトの血清尿酸值には性差があり, 男性では 思春期，女性では閉経期以降に上昇することか ら，血清尿酸值の調節に性ホルモンが関与して いると考えられる. 現在ヒトの血清尿酸值に影 響を与えることが報告されているトランスポー ターとして, URAT1（SLC22A12） とGLUT9 （SLC2A9）の二つがある。そのうち，URAT1の mRNA及び蛋白発現量は, マウス腎臓において メスよりもオスの方が高いことが報告されてい る. そこで, 性ホルモンによるURAT1の発現調 節機構を明らかにすることを目的として研究を 行つた.

\section{方法}

8週齢の雄性マウスに偽手術（Sham群）と精巣 摘出（ORX群）を行った。 8日間の回復期間後, ORX群に性ホルモン投与を8日間行った。投与し た性ホルモンは, エストラジオール, プロゲス テロン及びテストステロンであり，それぞれ $\mathrm{ORX}+\mathrm{E}$ 群, $\mathrm{ORX}+\mathrm{P}$ 群及びORX+T群とした。ま た，8週齢の雌性マウスに偽手術（Sham群）と卵 巣摘出 (OVX群) を行い, 雄性マウスと同様に OVX群に性ホルモン投与を行った。腎臓におけ るURAT1のmRNA量をreal-time PCR, 蛋白の発現 量をwestern blotを用いて比較した。

\section{結果}

雄性マウスのmRNA量は, Sham群と比較して ORX群で有意な減少, またORX群と比較して
$\mathrm{ORX}+\mathrm{T}$ 群で増加傾向が認められたが, 蛋白量に 有意な差は認められなかつた。また, ORX群と 比較してORX+E群でmRNA量に有意な差は認め られなかったが, 蛋白量に有意な減少が認めら れた。雌性マウスのmRNA量は，OVX群と比較 してOVX+P群で有意な増加が認められたが, 蛋 白量に有意な差は認められなかった。また, OVX群と比較してOVX+E群でmRNA量に有意な 差は認められなかつたが, 蛋白量に有意な減少 が認められた。

\section{考察}

雄性マウスではテストステロン投与, 雌性マ ウスではプロゲステロン投与でURAT1のmRNA 量は増加するが, 蛋白量は有意な差がなかった ことから翻訳の抑制や分解の克進が起こってい る可能性があると考えられる。 また，雄性及び 雌性マウスにおいてエストラジオール投与で URAT1の蛋白量は有意に減少するが, mRNA量 は有意な差がなかつたことから翻訳の抑制や分 解の克進が起こっている可能性が高いと考えら れる.

\section{結 語}

雄性マウスではテストステロン投与, 雌性マ ウスではプロゲステロン投与がURAT1の転写を 克進することが示唆された。 また, 雄性及び雌 性マウスにおいてエストラジオール投与が蛋白 発現を抑制することが示唆された. 